\title{
The Effect of the Use and Knowledge of AI on the Advanced Entrepreneurship in Saudis Small Business and Startups
}

\author{
Reem Mahmoud Ahmad Mashat ${ }^{1}$ \\ ${ }^{1}$ Business Administration, Faculty of Economics and Administration, King Abdulaziz University, Saudi Arabia \\ Correspondence: Reem Mahmoud Ahmad Mashat, Business Administration, Faculty of Economics and \\ Administration, King Abdulaziz University, Saudi Arabia. E-mail: rmashat1@gmail.com
}

Received: September 30, 2020

Accepted: November 2, 2020

Online Published: November 6, 2020

doi:10.5539/ijbm.v15n12p35

URL: https://doi.org/10.5539/ijbm.v15n12p35

\begin{abstract}
The study aims to study the actual use of the AI (Artificial intelligence) among small businesses in Saudi Arabia, and the effect of this use and the knowledge on the advanced entrepreneurship in these businesses. The actual use and knowledge were measured, along with the effect of these variables on the advanced entrepreneurship. The sample chosen was 204 small businesses and startups from three main cities in KSA. The sample was mostly of technology related businesses $45 \%$, and others as of service related and manufacturing simple products. The results show a lack of both the actual use of AI technology and knowledge of this technology. The results also show this lack is affecting the entrepreneurship of theses business and their abilities to grow with a sense of creativity in the local market. The research demonstrates the need for AI technology to strength the entrepreneurship among small business in Saudi Arabia. The research results close a gap in the available literature of small business use of technology and demonstrating advanced entrepreneurship in Kingdom of Saudi Arabia.
\end{abstract}

Further research is needed to understand the reasons of the lack of the use of AI among these businesses in Saudi Arabia.

Keywords: artificial intelligence, entrepreneurship, small businesses, startups

\section{Introduction}

Technology and digital technology are changing the way the world is today, and as the world is thriving in the shape of a fourth revolution depending on the new future brought by the modern technology, the world is developing the AI to do much of the human work and employ it by companies and organizations to leverage its profits and competition in the market. (Obschonka \& Audretsch, 2019). Modern digital technologies are transforming the nature and scope of entrepreneurial activity today by many means (Nambisan, 2017).

The new developments that the AI brought to the global industries that it enables machines to process large unstructured data sets by the use of complex, adaptive algorithms for the purpose of performing many tasks that originally need the human intelligence to perform (Choudhury et al., 2018)

With innovation and technological advancements, the most important factors that are pushing and supporting entrepreneurship and economic growth, the increase in what technology can do and new opportunities that it can brings to small companies and startups. But despite the big literature in the field of entrepreneurship, the uncertainty of the entrepreneurial process can limit the developments that can happen within this field (Ahmed, S. M. 2019).

There is a need to understand how new technological affordances can affect entrepreneurs and the creativity it requires, when launching a new venture (Townsend \& Hunt, 2019). Even with the high interest in the AI changes and new technologies that it brings but little has been written specifically on the entrepreneurship-AI intersection (Chalmers et al 2020).

In a country as Saudi Arabia, the country recognized the importance of entrepreneurship as an engine of growth and as the single most important player towards the modernization of its economy (Bokhari et al 2020). With all the societal benefits including innovation, reducing unemployment, satisfaction of new customer demands and increasing GDP of the country, the country is realizing the need for innovation and entrepreneurship with the aid of new technology. 
The original idea behind AI was to create a cognitive system that is similar or better than human intelligence which is a big and tough idea. AI can include all digital technologies that performs any tasks that save time on employees and owners of the business and does not need to mean advanced intelligence forms of technology and computers.

Today with the recent rise of AI because of the increase in the computational power and storage capacities, AI technology has begun to infiltrate the finance, healthcare, robotics, retail and insurance industry (Chalmers et al 2020). Saudi Arabia is also realizing this needs of the AI, and that can justified when reviewing the data of PwC's Data Analytics who developed the AI Impact Index ,of the USD 320 billion AI impact predicted for the Middle East, Saudi Arabia was expected to gain 12.4\% (USD 135.2 billion)- second only to the United Arab Emirates at $14 \%$. As the economy of any country depends on the small businesses, developing the small businesses and entrepreneurship in these businesses means developing the country's economy. The topic of this research is rarely researched in Saudi Arabia as there are low level of knowledge of the AI need for small businesses and the ability of the small businesses to demonstrate real entrepreneurship. This created a gap in the available literature and information of the use of AI among small businesses in KSA which reduce the ability of the government to focus on the right sectors and elements of the economy.

This means that all aspects of the country society starting with startups and entrepreneurship will be affected in a positive way. This research is studying the actual understand and use of AI among startups and small businesses in the country (KSA) to understand the total effect of the use of AI on them and the concept of entrepreneurship.

\section{Research Hypothesis}

The focus of the research is to measure the effect of the use of the AI and the actual knowledge on the advanced entrepreneurship in the small Saudi Businesses and startups. The review of the literature of the topic shows that this effect of the use of the AI is a positive effect on the entrepreneurship on small and medium businesses. The study of (Dubey, et al. (2020)) showed that the effect of AI and big data analysis for example is large on the entrepreneurship and the opposite (the rule of entrepreneurship on the adoption of the big data and AI) in positive way, thus the results shows that the adoption of AI in different types of the businesses is a positive support and push for the advanced entrepreneurship in the businesses. The study of Chalmers, et al, (2020). showed that there are positive results of the use of AI on entrepreneurship in different types of businesses, but in the same type it put small businesses at risks when competing with big businesses which use advanced AI technology. As this research focus on just the effect of the AI on the entrepreneurship in small businesses, the positive correlation and effect should be considered for this study.

The following hypothesis is developed accordingly:

H1: The use of AI in small businesses and startups in Saudi Arabia will have positive effect on the advanced entrepreneurship in these businesses.

The studies of (Soni et al 2019), (Metcalf et al,2019) (Borges et al 2020) suggested that there is lack of knowledge of the AI applications and (benefits / damages that can be caused by the AI use). These studies depended on articles reviews and primary data and was done recently on most of the areas of the use of the AI. The following hypotheses is developed accordingly:

H2: The lack of knowledge of the need of AI in small businesses in Saudi Arabia affect their entrepreneurship.

\section{Research Methodology}

The current research will use primary data, using a self-administrated questionnaire made for the purpose of this research, distributed on the research sample and analyzed by the use of statistical analysis package SPSS version 26. The population of the research is small business and startups in the three main cities in Saudi Arabia, Riyadh, Jeddah, and Damam. The sample is consisted of businesses and startups that can or did use new AI technologies in their businesses model and plans, to increase their profits and help reduce their costs. The study will focus on three main factors:

1. The actual use of any form of AI in the business.

2. The knowledge of AI use in the businesses and their benefits.

3. Weather AI can increase innovation and business entrepreneurship

The study population is estimated to be 5 thousand small businesses and startups in three main cities in KSA, according to the data published by the labor ministry in the year 2019 (Labor ministry yearly report 2019). To estimate the sample size, the Yamane's (1967) formula is used in this paper.

$$
n=N / 1+N(e) 2
$$


$\mathrm{N}$ is the study population $=5000$

e the precision level. The precision level is presumed to be 0.07

$\mathrm{n}=5000 / 5000(0.07) 2$

$\mathrm{n}=204$ small businesses and startups.

The research sample is 204 businesses, were chosen randomly regarding they included in the conditions imposed in this research which are as the following:

1. A small business or a startup (employees' number is less than 20)

2. Starting actual work less than 5 years.

The questionnaire is distributed on the owners of the businesses or the head of the company and small businesses through electronic emails after contacting them and asking them to participate in the research and explaining the goal of the research and the its scope.

\subsection{Questionnaire Design}

The research tool is self-administrated questionnaire that was developed to according three main factors as the following:

1. The actual use of any form of $\mathrm{AI}$ in the business.

2. The knowledge of AI use in the businesses and their benefits.

3. Weather AI can increase innovation and business entrepreneurship.

The reliability statistics results showed that the internal consistency among the questionnaire items is under the acceptable range (Nunnally, 1978). The reliability statistics are at the acceptable level as the following:

Table 1. Reliability test

\begin{tabular}{ll}
\hline Cronbach's Alpha & N of questions \\
\hline 0.811 & 12 \\
\hline
\end{tabular}

\section{Results}

The data was collected from all respondents and the number of the completed questionnaires was 190 questionnaires (93\%). The questionnaires were distributed between June 2020 and August 2020.

The first section of the questionnaire was of demographic data as the following:

Table 2. Demographic data

\begin{tabular}{llllll}
\hline Type of the business & N/ Percentage & Working years & N/percentage & City & N/percentage \\
\hline Technology related business & $85 / 45 \%$ & Less than one year & $75 / 39 \%$ & Riyadh & $120 / 63 \%$ \\
Retail & $55 / 29 \%$ & $1-3$ years & $88 / 46 \%$ & Jeddah & $44 / 23 \%$ \\
Manufacturing of simple products & $2 / 1 \%$ & $3-5$ years & $27 / 15 \%$ & Damam & $26 / 14 \%$ \\
Service provider online/ offline services & $48 / 25 \%$ & & & \\
\hline
\end{tabular}

The businesses included in this research were $45 \%$ a technology related business, $29 \%$ retail businesses, $25 \%$ service providers and only $1 \%$ manufacturing businesses of simple products. $46 \%$ of the businesses were working for $1-3$ years, $38 \%$ for less than one year, and 15\% 3-5 years. most of the businesses or $64 \%$ were operating in Riyadh, $23 \%$ in Jeddah, and only $14 \%$ of them were based in Damam.

\section{Results of the Second Section of the Questionnaire: The Actual Use of Any Form of AI in the Business}


Table 3. The actual use of any form of AI in the business

\begin{tabular}{|c|c|c|c|c|c|}
\hline Question / statement & $\begin{array}{l}\text { Strongly } \\
\text { agree }\end{array}$ & Agree & $\begin{array}{l}\text { I don't } \\
\text { know }\end{array}$ & Disagree & $\begin{array}{l}\text { Strongly } \\
\text { disagree }\end{array}$ \\
\hline $\begin{array}{l}\text { We use simple forms of AI technology in our business as } \\
\text { spam filters or automated responders and online customer } \\
\text { support }\end{array}$ & $32 / 17 \%$ & $120 / 63 \%$ & 0 & $33 / 17 \%$ & $5 / 3 \%$ \\
\hline We use / used sales and business forecasting & $16 / 8 \%$ & $44 / 23 \%$ & 0 & $121 / 64 \%$ & $14 / 7 \%$ \\
\hline $\begin{array}{l}\text { We use / used product recommendations and purchase } \\
\text { predictions }\end{array}$ & 0 & $17 / 9 \%$ & 0 & $133 / 71 \%$ & $45 / 20 \%$ \\
\hline $\begin{array}{l}\text { We used an automated web design for online sales and } \\
\text { marketing of the business }\end{array}$ & $155 / 81 \%$ & $25 / 14 \%$ & 0 & $6 / 3 \%$ & $4 / 2 \%$ \\
\hline
\end{tabular}

For the first statement, $63 \%$ agreed, $17 \%$ strongly agreed, $17 \%$ disagreed, and only $3 \%$ strongly disagreed. For the second statement $64 \%$ disagreed, $23 \%$ agreed, $8 \%$ strongly agreed, $7 \%$ strongly agreed. In the third statement $71 \%$ disagreed, $20 \%$ strongly disagreed, $9 \%$ agreed. The fourth statement, $81 \%$ strongly agreed, $14 \%$ agreed, $3 \%$ disagreed, $2 \%$ strongly disagreed.

Table 4. The knowledge of AI use in the businesses and their benefits

\begin{tabular}{|c|c|c|c|c|c|}
\hline Question / statement & $\begin{array}{l}\text { Strongly } \\
\text { agree }\end{array}$ & Agree & $\begin{array}{l}\text { I don't } \\
\text { know }\end{array}$ & Disagree & $\begin{array}{l}\text { Strongly } \\
\text { disagree }\end{array}$ \\
\hline AI technology can leverage business sales and reduce costs & $32 / 17 \%$ & $100 / 53 \%$ & $10 / 5 \%$ & $48 / 25 \%$ & 0 \\
\hline $\begin{array}{l}\text { AI technology can be used in all types of businesses for the } \\
\text { increase of the business innovation }\end{array}$ & $20 / 11 \%$ & $120 / 63 \%$ & $11 / 6 \%$ & $44 / 23 \%$ & 0 \\
\hline $\begin{array}{l}\text { AI technology is used for customers care and automated } \\
\text { responses' }\end{array}$ & $25 / 15 \%$ & $77 / 40 \%$ & $25 / 15 \%$ & $18 / 10 \%$ & $45 / 20 \%$ \\
\hline AI is used to increase the business competitiveness in the market. & $33 / 17 \%$ & $23 / 13 \%$ & $48 / 25 \%$ & $70 / 37 \%$ & $16 / 8 \%$ \\
\hline
\end{tabular}

For the third part of the questionnaire, on the first statement 53\% agreed, $25 \%$ disagreed, $17 \%$ strongly agreed, $5 \%$ said they don't know. The second statement, $63 \%$ agreed, $23 \%$ disagreed, $11 \%$ strongly agreed, $6 \%$ said don't know. On the third statement, $40 \%$ agreed, $20 \%$ strongly disagreed, $15 \%$ strongly agreed, $15 \%$ said they don't know, $10 \%$ disagreed.

On the last statement of this section, $37 \%$ said they disagree, $25 \%$ said they don't know, $17 \%$ said strongly agree, $13 \%$ agreed, and only strongly disagreed.

Table 5. Wither AI can increase innovation and business entrepreneurship

\begin{tabular}{|c|c|c|c|c|c|}
\hline Question / statement & $\begin{array}{l}\text { Strongly } \\
\text { agree }\end{array}$ & Agree & $\begin{array}{l}\text { I don't } \\
\text { know }\end{array}$ & Disagree & $\begin{array}{l}\text { Strongly } \\
\text { disagree }\end{array}$ \\
\hline $\begin{array}{l}\text { AI can increase entrepreneurs' abilities to predict the market and } \\
\text { new ideas }\end{array}$ & 0 & $110 / 58 \%$ & $51 / 27 \%$ & $34 / 18 \%$ & 0 \\
\hline $\begin{array}{l}\text { AI is an advantage for entrepreneurs in the expanding global } \\
\text { market }\end{array}$ & 0 & $109 / 57 \%$ & $38 / 20 \%$ & $28 / 15 \%$ & $20 / 11 \%$ \\
\hline $\begin{array}{l}\text { AI leverage the innovation levels for any business of all types } \\
\text { and sizes }\end{array}$ & & $40 / 20 \%$ & $105 / 55 \%$ & $40 / 20 \%$ & $10 / 5 \%$ \\
\hline $\begin{array}{l}\text { AI is needed to be used in my business at the moment for better } \\
\text { performance and innovation }\end{array}$ & $27 / 14 \%$ & $105 / 54 \%$ & $31 / 16 \%$ & $15 / 8 \%$ & $17 / 8 \%$ \\
\hline
\end{tabular}

On the first statement, $58 \%$ agreed, $27 \%$ said they don't know, $18 \%$ disagreed. On the second statement $57 \%$ agreed, $20 \%$ said they don't know, $15 \%$ disagreed, $11 \%$ strongly disagreed. Next on the third statement, $55 \%$ said they don't know, $20 \%$ agreed, $20 \%$ disagreed, 5\% strongly disagreed. The last statement, $54 \%$ agreed, $16 \%$ said they don't know $14 \%$ strongly agreed, $8 \%$ disagreed, and 85 strongly disagreed. 


\subsection{Hypothesis Testing}

To test the given first hypothesis in this study, the correlation of the two factors of the actual use of the AI and the effect on advanced entrepreneurship in small businesses.

The results show positive correlation of $(p=0.023<0.05)$, between the two variables which indicates that the actual use of the AI will increase the advanced entrepreneurship in these businesses.

On the second hypothesis, the correlation test done on the two variables, the knowledge of the AI and the effect on the advanced entrepreneurship in these businesses, and the results showed positive correlation between the two variables $(\mathrm{p}=0.002<0.05)$.

The results show that the lack of the knowledge of the AI among small businesses will affect their advanced entrepreneurship and creativity.

\section{Discussion}

The need for AI comes from the need for advanced tools to develop the businesses to be able to compete in the global market, thus small businesses will need AI to perform high tasks for better advanced entrepreneurship and creativity. The results of this research shows that there a lack of knowledge of the need of AI among the small businesses and startups and average actual use of the simple tools of the AI as automated web design for online sales and marketing of the business, and no advanced tools. The lack of the knowledge of the AI was clear among these businesses and startups, which affected their advanced entrepreneurship and creativity. These businesses presented in three major cities in Saudi Arabia, high percentage of them $45 \%$ are technology related, yet there is a lack of knowledge of the use of the AI, which will affect their actual advanced entrepreneurship and creativity in the upcoming years. As the data of the Saudi government shows for the years 2019 and 2018 reduction in the startups and small businesses life duration and shortage of new emergence businesses in the country, the data of this research shows that AI can be one factor that could increase the ability of these small businesses to survive big market (local and global). The results clearly show the need for higher usage and knowledge of the AI in small businesses in particular to be able to survive and to expand its life in local Saudi market. Studies reviewed during the writing of the hypothesis in this research indicated that there are negative impacts of the use of AI by big companies on the small businesses, which explained in this study by the lack of knowledge and actual usage of the $\mathrm{AI}$ in the small businesses, which give high advantage to the big organizations over small businesses.

\section{Conclusion}

The advanced technology changed the needs of small businesses to grow, and AI technology became the key for the growth of big businesses and organizations which affected the ability of small businesses to survive, but in the same way, the use of AI technology by these small businesses will make it able to compete with big companies and both global and local markets.

The current research focused on the small businesses in Saudi Arabia in the local market, and their use of the AI, which was clear that they use some parts of the AI available for them and not the full technology that can increase their entrepreneurship and creativity in their areas. On the view of this research, there are need for further researches on the actual reasons of lack of the use of the AI and the lack of the knowledge among small businesses in Saudi Arabia, especially when $45 \%$ of these businesses are technology related. The need for further research on the topic is great as small businesses and startups are the main pillars of any emerging economy around the world.

\section{References}

Ahmed, S. M. (2019). Artificial intelligence in Saudi Arabia: Leveraging entrepreneurship in the Arab markets. In 2019 Amity International Conference on Artificial Intelligence (AICAI) (pp. 394-398). IEEE.

Bokhari, A., Alothmany, N., \& Magbool, S. (2012). Entrepreneurship and Unemployment in The Kingdom of Saudi 398 Arabia. In Saudi Economy Conference: Challenges and Opportunities.

Borges, A. F., Laurindo, F. J., Spínola, M. M., Gonçalves, R. F., \& Mattos, C. A. (2020). The strategic use of artificial intelligence in the digital era: Systematic literature review and future research directions. International Journal of Information Management.

Chalmers, D., MacKenzie, N. G., \& Carter, S. (2020). Artificial Intelligence and Entrepreneurship: Implications for Venture Creation in the Fourth Industrial Revolution. Entrepreneurship Theory and Practice. 
Choudhury, P., Starr, E., \& Agarwal, R. (2018). Machine learning and human capital: experimental evidence on productivity complementarities. Harvard Business School.

Dubey, R., Gunasekaran, A., Childe, S. J., Bryde, D. J., Giannakis, M., Foropon, C., ... \& Hazen, B. T. (2020). Big data analytics and artificial intelligence pathway to operational performance under the effects of entrepreneurial orientation and environmental dynamism: A study of manufacturing organisations. International Journal of Production Economics, 226.

Metcalf, L., Askay, D. A., \& Rosenberg, L. B. (2019). Keeping humans in the loop: pooling knowledge through artificial swarm intelligence to improve business decision making. California Management Review, 61(4), 84-109.

Nambisan, S. (2017). Digital entrepreneurship: Toward a digital technology perspective of entrepreneurship. Entrepreneurship Theory and Practice, 41(6), 1029-1055.https://doi.org/10.1111/etap.12254

Obschonka, M., \& Audretsch, D. B. (2019). Artificial intelligence and big data in entrepreneurship: A new era has begun. Small Business Economics, 19(1). https://doi.org/10.1007/s11187-019-00202-4

PwC. (2018). US $\$ 320$ billion by 2030 ? The potential impact of AI in the Middle East. Retrieved from https://www.pwc.com/m1/en/publications/documents/economic -potential-ai-middle-east.pdf

Soni, N., Sharma, E. K., Singh, N., \& Kapoor, A. (2019). Impact of artificial intelligence on businesses: from research, innovation, market deployment to future shifts in business models.

Townsend, D. M., \& Hunt, R. A. (2019). Entrepreneurial action, creativity, \& judgment in the age of artificial intelligence. Journal of Business Venturing Insights, 11, 126. https://doi.org/10.1016/j.jbvi. 2019.e00126

\section{Copyrights}

Copyright for this article is retained by the author(s), with first publication rights granted to the journal.

This is an open-access article distributed under the terms and conditions of the Creative Commons Attribution license (http://creativecommons.org/licenses/by/4.0/). 